\title{
Genetic diversity of Vriesea cacuminis (Bromeliaceae): an endangered and endemic Brazilian species
}

\author{
P.C.C. Ribeiro' ${ }^{1}$ L.C. Pinheiro ${ }^{1}$, R. Domingues ${ }^{2}$, R.C. Forzza ${ }^{3}$, \\ M.A. Machado ${ }^{2}$ and L.F. Viccini ${ }^{1}$ \\ ${ }^{1}$ Departamento de Biologia, Universidade Federal de Juiz de Fora, \\ Juiz de Fora, MG, Brasil \\ ${ }^{2}$ Empresa Brasileira de Pesquisa Agropecuária Gado de Leite, \\ Dom Bosco, Juiz de Fora, MG, Brasil \\ ${ }^{3}$ Jardim Botânico do Rio de Janeiro, Rio de Janeiro, RJ, Brasil \\ Corresponding author: L.F. Viccini \\ E-mail: lyderson.viccini@ufjf.edu.br
}

Genet. Mol. Res. 12 (2): 1934-1943 (2013)

Received November 23, 2012

Accepted March 29, 2013

Published June 13, 2013

DOI http://dx.doi.org/10.4238/2013.June.13.2

\begin{abstract}
Data about the genetic structure can help to understand the evolutionary process of natural populations as well as to drive strategies of conservation. Vriesea cacuminis, an endemic Brazilian Bromeliad, has been found in 2 areas of Minas Gerais State. One is a legal preservation unit (Ibitipoca State Park) and the other an unprotected area (Serra Negra). The 2 areas belong to the Mantiqueira Mountain Range Complex; both are characterized by steep relief with high altitudes and by heterogenic vegetation formed by a mosaic of rocky fields and forest fragments. According to International Union for Conservation of Nature criteria, $V$. cacuminis is designated as "vulnerable". We examined the genetic variability and population structure of 70 individuals (3 populations) of $V$. cacuminis, using 16 ISSR markers. Although $V$. cacuminis is considered a rare species, the estimated genetic diversity was found to be relatively high (Shannon index $=0.33$; percentage
\end{abstract}


of polymorphic bands $=87 \%$ ). The populations were found not to be structured (AMOVA test, $\Phi_{\mathrm{ST}}=0.16$ ), probably due to the cross-breeding. Based on Bayesian analysis, this species includes one cluster containing the populations from Ibitipoca State Park and another cluster including the population from Serra Negra. This information will help determine strategies to maintain the genetic variability of these populations.

Key words: Bromeliaceae; Vriesea cacuminis; Endemism; Conservation; Genetic diversity

\section{INTRODUCTION}

Genetic structure data on natural plant populations have helped to understand the adaptation process, speciation, gene flow, and how ecological and evolutionary processes can influence the dynamics of natural plant populations (Barbará et al., 2009; Lousada et al., 2011). Moreover, these studies can help to define priority locations to be preserved by law and also to develop conservation strategies (Holsinger and Gottieb, 1991). The amount of genetic variability can also be related to the survival time of one population, since high genetic diversity normally increases the chance of adaptation and consequently influences how long it can survive (Neel and Cummings, 2003). Although it is possible to observe small populations with restricted distribution and high variability (Viccini et al., 2004; Hmeljevski et al., 2011), in general, rare and endemic species show a lower level of genetic diversity compared to widely distributed ones (Gitzendanner and Soltis, 2000).

Due to the occurrence of several species at high altitudes, bromeliads can help us to understand the speciation process and genetic variability distribution in tropical inselbergs. The family Bromeliaceae comprises nearly 3172 species distributed in 58 genera (Luther, 2010) mainly with Neotropical distribution. An exception is Pitcairnia feliciana, which occurs in Africa (Jacques-Felix, 2000). Around 1030 of 1207 Brazilian species are endemic, making this country one of the most important ones regarding the family diversity (Forzza et al., 2013). On the other hand, the destruction of the ecosystem and the predatory extraction of those plants have caused a drastic reduction in the number and size of populations and, therefore, loss of genetic diversity (Martinelli et al., 2008; Barbará et al., 2009). Vriesea cacuminis L.B.Sm. is an example of a rare bromeliad, which is restricted to 2 places in Minas Gerais State, Brazil, $30 \mathrm{~km}$ apart: Ibitipoca State Park, a State conservation unit, and Serra Negra, an unprotected area (Versieux, 2011). Both locations belong to the Mantiqueira Range Complex and are characterized by a steep relief with altitudes ranging from 900 to $1794 \mathrm{~m}$ and heterogeneous vegetation composed of a mosaic of rocky fields and forest fragments (Menini et al., 2009). The species can be seen in the rocky landscapes mainly at altitudes higher than $1400 \mathrm{~m}$ (Monteiro and Forzza, 2008). Due to its restricted distribution, V. cacuminis has been included in the Brazilian lists of threatened species, classified as vulnerable (Versieux and Wendt, 2007; Drummond et al., 2009), and it was categorized as a species with insufficient data by the official Brazilian Red List (MMA, 2008).

Nowadays, genetic variability has been investigated mainly at the DNA level. The inter-simple sequence repeat (ISSR) is one of the markers that has been used to study the variability of natural plant populations. This PCR-based method does not require prior genomic 
sequence information since the ISSR primers anneal close to microsatellite regions, which occur randomly in eukaryotic genomes. As a result, several markers can be amplified from a single reaction and can be highly variable at the intraspecific level (Wolfe, 2005).

Here, we report on the use of ISSR markers to investigate the genetic variability of all known populations of $V$. cacuminis. It was possible to compare the diversity between protected and unprotected areas. In addition, possible mechanisms of species dispersion between the 2 mountain ridges and also how population variability can be maintained are discussed.

\section{MATERIAL AND METHODS}

\section{Population sampling}

Leaves of $V$. cacuminis were collected from 2 populations at Ibitipoca State Park (Peão, S21 ${ }^{\circ} 42^{\prime} 7.9^{\prime \prime}$ and W43 ${ }^{\circ} 52^{\prime} 35.1^{\prime \prime}$, with an elevation of $1578 \mathrm{~m}$ and Cruzeiro, S21 ${ }^{\circ} 41^{\prime} 44.4^{\prime \prime}$ and W43 $53^{\prime} 49.6^{\prime \prime}$, with an elevation of $1670 \mathrm{~m}$ ) and 1 population in the Serra Negra range (S21 ${ }^{\circ} 57^{\prime} 57^{\prime \prime}$ and W43 $53^{\prime} 13.1^{\prime \prime}$, with an elevation of $1592 \mathrm{~m}$ ), both located in Minas Gerais State, Brazil (Figure 1). Nearly $300 \mathrm{mg}$ of young leaves was collected from 20, 29, and 21 individuals of Peão, Cruzeiro, and Serra Negra populations, respectively. Due to wider distribution of Cruzeiro population, the individuals were sampled at 4 different points (Figure 1).

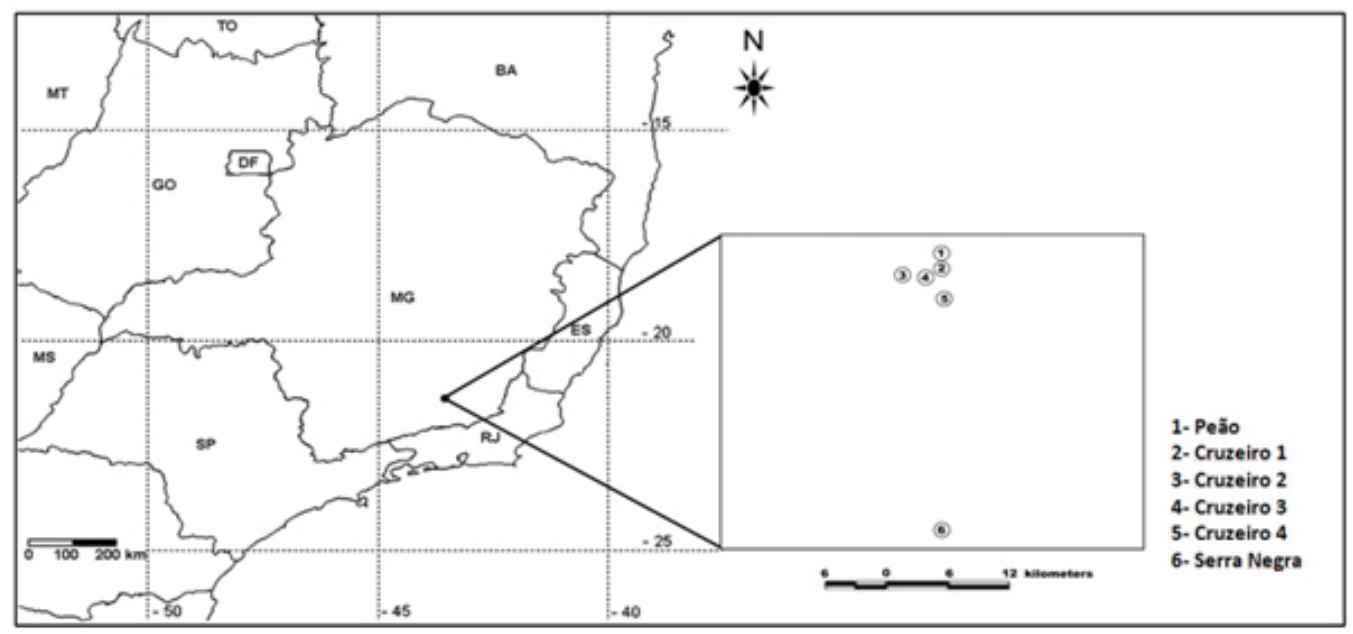

Figure 1. Geographical locations of 3 populations of Vriesea cacuminis at Minas Gerais State: 1 - Population 1 (Peão; range $=200 \mathrm{~m}) ; 2$ to 5 - Population 2 (Cruzeiro: range $=3 \mathrm{~km}$ ); 6 - Population 3 (Serra Negra: range $=150$ $\mathrm{m})$. The average distance between population 1 and population 2 is nearly $3 \mathrm{~km}$. The average distance between 5 sampling points of the population 2 is $600 \mathrm{~m}$ and the distance between populations 1, 2 (Ibitipoca State Park), and 3 (Serra Negra) is approximately $30 \mathrm{~km}$.

\section{DNA extraction and PCR amplification}

DNA extraction was performed according to Ferreira and Grattapaglia (1998), with 
few modifications. Each DNA sample was quantified using a Nanodrop ND-100 spectrophotometer (Nanotrop, USA) and stored at $-20^{\circ} \mathrm{C}$. Initially, 30 anchored primers developed at University of British Columbia were tested. From those, 16 primers that showed good patterns of amplification were selected (Table 1).

\begin{tabular}{|c|c|c|c|}
\hline Primer & Sequence (5'-3') & No. of loci detected & PPB \\
\hline UBC- 808 & AGAGAGAGAGAGAGAGC & $3(2)$ & 66.6 \\
\hline UBC- 815 & СТСТСТСТСТСТСТСТG & $7(7)$ & 100.0 \\
\hline UBC- 818 & CACACACACACACACAG & $8(8)$ & 100.0 \\
\hline UBC-820 & GTGTGTGTGTGTGTGTC & $2(2)$ & 100.0 \\
\hline UBC- 823 & ТСТСТСТСТСТСТСТСС & $5(4)$ & 80.0 \\
\hline UBC-824 & ТСТСТСТСТСТСТСТСG & $4(4)$ & 100.0 \\
\hline UBC-827 & ACACACACACACACACG & $2(2)$ & 100.0 \\
\hline UBC- 835 & AGAGAGAGAGAGAGAGYC & $5(4)$ & 80.0 \\
\hline UBC- 841 & GAGAGAGAGAGAGAGAYC & $7(6)$ & 85.7 \\
\hline UBC- 842 & GAGAGAGAGAGAGAGAYG & $6(5)$ & 83.3 \\
\hline UBC-844 & СTCTCTCTCTCTCTCTRC & $7(6)$ & 85.7 \\
\hline UBC-845 & СТCTCTCTCTCTCTCTRG & $6(4)$ & 66.6 \\
\hline UBC- 848 & CACACACACACACACARG & $4(3)$ & 75.0 \\
\hline UBC- 850 & GTGTGTGTGTGTGTGTYC & $8(7)$ & 87.5 \\
\hline UBC-851 & GTGTGTGTGTGTGTGTYG & $5(4)$ & 80.0 \\
\hline UBC-857 & ACACACACACACACACYG & $7(7)$ & 100.0 \\
\hline
\end{tabular}

Numbers in parentheses refer to the number of polymorphic bands/primer.

ISSR markers were obtained according to Meloni et al. (2006), with minor modifications. The reaction was carried out in a volume of $25 \mu \mathrm{L}$ containing $0.5 \mu \mathrm{M}$ primer, $0.15 \mathrm{mM}$ dNTPs, $1.0 \mathrm{U}$ Taq DNA polymerase (Promega), $10 \mathrm{mM}$ Tris-HCl, pH 8.0, $2 \mathrm{mM} \mathrm{MgCl}_{2}, 50$ $\mathrm{mM} \mathrm{KCl}$, and $30 \mathrm{ng} / \mu \mathrm{L}$ template DNA. DNA amplification was performed in a GeneAmp PCR System 9700 thermocycler (Applied Biosystems, Perkin Elmer) with the following conditions: 4 min at $94^{\circ} \mathrm{C}$ followed by 45 cycles of $1 \mathrm{~min}$ at $94^{\circ} \mathrm{C}, 45 \mathrm{~s}$ annealing at $50^{\circ} \mathrm{C}$ and a 2-min extension at $72^{\circ} \mathrm{C}$, and finally an extension cycle of $7 \mathrm{~min}$ at $72^{\circ} \mathrm{C}$. DNA fragments from PCR amplification were loaded on a $1.5 \%$ agarose gel and submitted to electrophoresis using $1 \mathrm{X}$ TBE buffer ( $100 \mathrm{~V}$ for $4 \mathrm{~h}$ ), stained with $3 \mu \mathrm{g} / \mathrm{mL}$ ethidium bromide for $30 \mathrm{~min}$ and photodocumented with the EagleEye (Stratagene) system. The molecular weight of the fragments was estimated using a molecular marker ladder of $100 \mathrm{bp}$ (Amresco).

\section{Data analysis}

Only consistent bands were used. ISSR bands were considered as present (1) or absent (0), and a binary qualitative matrix was made and analyzed using the GENES software (Cruz, 1998). These data were used to make a dissimilarity matrix based on the complement of the Jaccard index $(I)$, determined as 1-S. The Jaccard index was calculated by the expression: $S i j=$ $\mathrm{a} /(\mathrm{a}+\mathrm{b}+\mathrm{c})$, with $a$ being the number of bands shared by the sample pair $(i$ and $j)$, and $b$ and $c$ the number of bands present in samples $i$ and $j$, respectively (Sneath and Sokal, 1973). A dendrogram was also constructed by an unweighted paired group method of cluster analysis using arithmetic averages (UPGMA). Bootstrapping based on the fingerprinting data was carried out using 1000 replicates. Analysis of molecular variance (AMOVA) was performed as described 
by Excoffier (1992). Additionally, an estimate of the hierarchical variability was obtained by the Shannon index (Bussell, 1999) using the expression: $\mathrm{H}=-\Sigma \mathrm{Pi} \log 2 \mathrm{Pi}$, where $P i$ is the frequency of a given ISSR band. The index was calculated for each locus $\left(H_{\mathrm{O}}\right)$. The average of all markers within a population was called H'pop and the average of H'pop within species was called Hpop. The average of all markers within species, without considering populations, was designated Hsp. The within-population component was calculated as (Hsp - Hpop) / Hsp, and the between-population component as Hpop/Hsp. The POPGENE software (Yeh et al., 1997) was used to estimate the Shannon index and calculate the percentage of polymorphic bands (PPB). PPB was used as descriptive information and was obtained dividing the number of polymorphic bands at the population and species levels by the total number of scored bands. A Bayesian analysis was performed using the STRUCTURE 2.3.3 software (Hubisz et al., 2009) to infer the number of genetic clusters (K). Ten independent runs were performed with a 100,000 burn-in period length and 500,000 Markov chain Monte Carlo replicates after burn-in, testing from 1 to 8 genetic clusters $(K=1-8)$. Parameter sets assumed the admixture model with alleles correlated between populations. We determined the average of each $\mathrm{K}$ likelihood value, 'log of probability' $[\mathrm{LnP}(\mathrm{D})]$ through all runs to infer the number of genetic clusters (populations) as suggested by Pritchard et al. (2000). The statistic $\Delta K$ was estimated according to Evanno et al. (2005).

\section{RESULTS}

The 16 selected ISSR primers yielded 86 steady markers in 70 individuals. The molecular weight ranged from 200 to $1100 \mathrm{bp}$. Table 1 summarizes the number of fragments and the PPB observed for each primer. The average number of bands per primer was 5.3 and the PPB ranged from 66 to $100 \%$. Several markers were population-specific. Of 86 markers, 10 were observed only in 1 population while the others were observed in at least 2 populations (data not shown).

Table 2 summarizes the estimated diversity for each population and also for the species (without population structure). Population 2 (Cruzeiro) showed the highest level of variability. The PPB was $76.5 \%$, the Shannon index was $\mathrm{H}=0.31$, and the mean of dissimilarity (D) among individuals was 0.3 . Population 3 (Serra Negra) showed less diversity ( $\mathrm{PPB}=45.88 \%, \mathrm{H}=0.22$, $\mathrm{D}=0.21$ ). Diversity was always lower at the population level than at the species level. The PPB for the species was $87.06 \%$ and the Shannon index was 0.33 .

Table 2. Number of individuals $(\mathrm{N})$ and genetic variation of Vriesea cacuminis populations.

\begin{tabular}{llccc}
\hline V. cacuminis population & N & PPB & H & D \\
\hline Population 1 (Peão) & 20 & 68.24 & 0.29 & 0.26 \\
Population 2 (Cruzeiro) & 29 & 76.50 & 0.31 & 0.30 \\
Population 3 (Serra Negra) & 21 & 45.88 & 0.22 & 0.21 \\
Species & 70 & 87.06 & 0.33 & 0.29 \\
\hline
\end{tabular}

$\mathrm{PPB}=$ percentage of polymorphic bands; $\mathrm{H}=$ Shannon index; $\mathrm{D}=$ dissimilarity average calculated using an average of the Jaccard index (1-S).

Clones were identified only in 2 individuals of Population 1 (Peão). The Jaccard similarity index was the same between 2 pairs of individuals collected side by side in the field. Therefore, it was possible to identify 68 different genotypes among 70 individuals investigated. 
The partition of the variability - AMOVA - revealed significant differentiation $(\mathrm{P}<$ 0.001 ) between populations (about $16 \%$ from the total diversity). The remaining $84 \%$ was distributed between individuals within populations (Table 3). Similarly, by the Shannon diversity index, the estimated diversity within populations (Hpop/Hsp) was $81 \%$ and between populations [(Hsp - Hpop) / Hsp] was 19\%.

Table 3. Analysis of molecular variance of Vriesea cacuminis populations.

\begin{tabular}{lrrrrr}
\hline Source of variance & d.f. & SSD & \% of total variance & P value & $\Phi$-statistics \\
\hline Among populations & 2 & 78.05 & 15.96 & $<0.001$ & $\Phi_{\text {ST }}=0.1596$ \\
Within populations & 67 & 487.29 & 84.04 & $<0.001$ & $1-\Phi_{\text {ST }}=0.8404$ \\
Total & 69 & 565.34 & 100.00 & & \\
\hline
\end{tabular}

d.f. $=$ degrees of freedom; SSD $=$ sum of squared deviations.

Even if the dendrogram constructed using the UPGMA algorithm with the similarity matrix based on the Jaccard coefficient (Sneath and Sokal, 1973) did not group the populations with high bootstrap support (data not shown), the cluster using Bayesian analysis (Evanno et al., 2005) indicated that $\mathrm{K}=2$ was the most likely structure of the populations. There was one major genetic cluster containing the populations from Ibitipoca Park (Peão and Cruzeiro) and another with populations from Serra Negra (Figure 2).
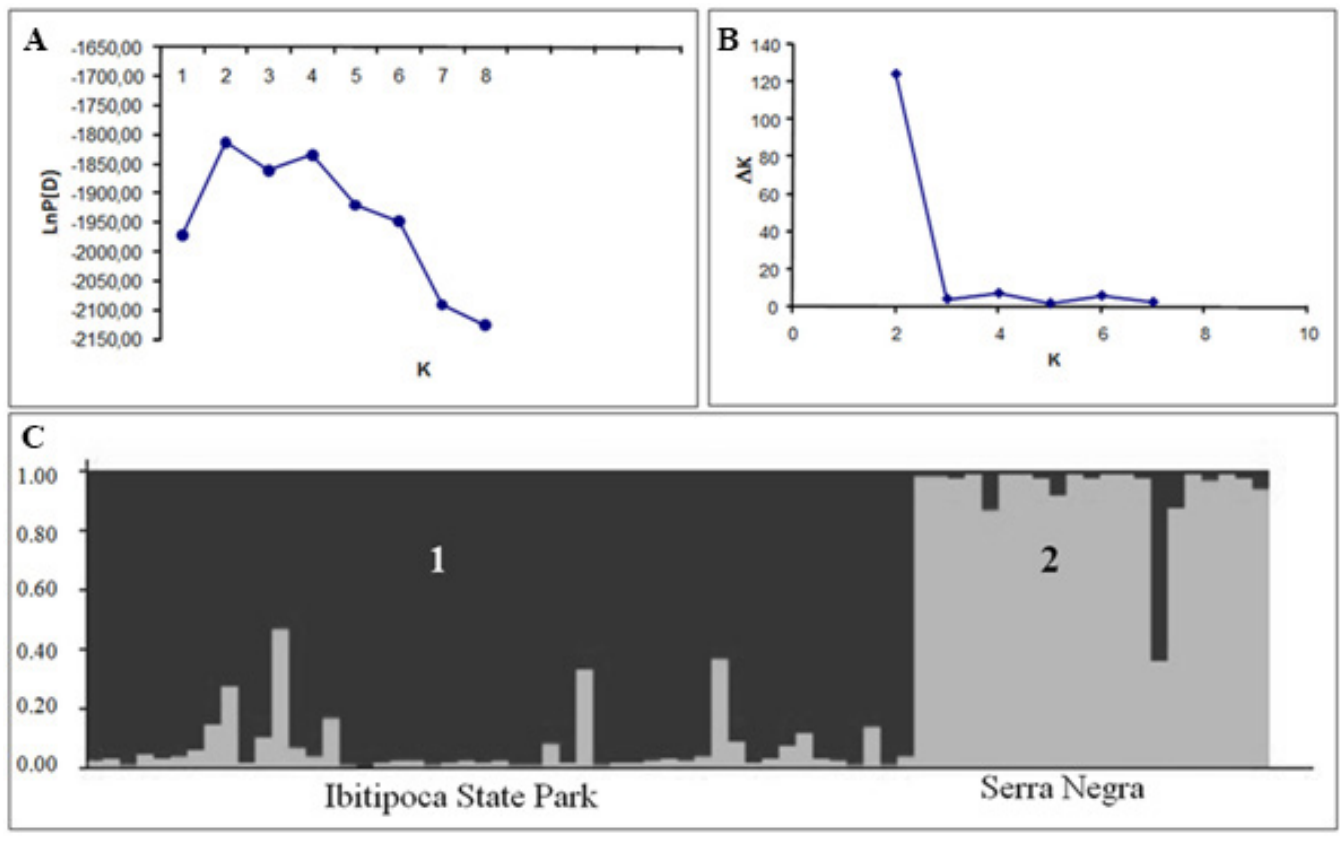

Figure 2. Bayesian analysis of 70 individuals from 3 populations of Vriesea cacuminis. A. Average log probability of data $\mathrm{LnP}(\mathrm{D})$ for each $\mathrm{K}$ of 10 independent runs (likely number of populations $=2$ ). B. Average $\Delta \mathrm{K}$ for each $\mathrm{K}$ of 10 independent runs (likely number of populations $=2$ ). C. Graphic representation of the different genetic pools for $\mathrm{K}=2$. The first genetic group (1) is depicted in black (most of individuals from Ibitipoca range) and the second group (2) is depicted in gray (most of individuals from Serra Negra range). 
P.C.C. Ribeiro et al.

\section{DISCUSSION}

Ibitipoca State Park is a protected area with 1488 ha that hosts a great number of endemic species, including some that belong to the family Bromeliaceae (Monteiro and Forzza, 2008). Despite the large diversity, few studies about the genetic diversity and population structure of these species have been carried out.

Considered as a rare, restricted and endemic species, $V$. cacuminis has a relatively high genetic diversity assessed by ISSR markers ( $\mathrm{PPB}=87 \%$ and $I=0.33 \%$ ). Although higher genetic diversity has been mainly related to wider distributed species (Souza and Lovato, 2010), geographically restricted species have also shown relatively high diversity index (Cavallari et al., 2006; Huang et al., 2008). Consequently, these data provide evidence that other factors, in addition to geographical distribution, could contribute to maintain the variability in rare and restricted species.

As was already observed for other species, including the Bromeliaceae, the level of diversity varies according to population size (Hmeljevski et al., 2011). For V. cacuminis, Population 2 (Cruzeiro), which was the largest population, showed the highest genetic diversity ( $\mathrm{PPB}=76.5 \%, I=0.31, \mathrm{D}=0.3)$. On the other hand, the lowest values of genetic diversity $(\mathrm{PPB}=45.88 \%, I=0.22, \mathrm{D}=0.21)$ were observed for Population 3 (Serra Negra), which had the smallest number of individuals concentrated on a rock wall $150 \mathrm{~m}$ long. Population 1

(Peão) showed intermediate values of diversity, as compared to the others, and it was formed by individuals scattered on a steep rocky outcrop.

The capacity of dispersion and the reproduction system are also important factors in determining the structure and the diversity of plant populations. Previous studies have suggested that a significant difference between 2 populations occurs when the rate of genetic differentiation (e.g., Gst or $\Phi$ st) is higher than 0.25 (Slatkin, 1987; Han et al., 2007). Our data for $V$. cacuminis do not suggest considerable distinction between the 3 populations, since genetic differentiation between populations, indicated by $\Phi$ st, was only 0.16 . Similarly, using the UPGMA algorithm, it was not possible to observe clusters among populations with high bootstrap support, which suggests the absence of a clear differentiation between the 2 populations of the Ibitipoca State Park (Peão and Cruzeiro) and also between these populations and the Serra Negra population. On the other hand, Bayesian clustering analysis showed 2 distinct clusters among Ibitipoca Park and Serra Negra populations. AMOVA also indicated that part of the diversity is distributed among populations, supporting the split of the individuals into 2 major groups (Ibitipoca and Serra Negra).

Regarding plant reproductive strategies, a mixed system of vegetative reproduction and outcrossing, commonly observed in species of Bromeliaceae (Benzing, 2000), also seems to be responsible for maintaining the population structure of $V$. cacuminis. Field observations revealed evidence of vegetative propagation and ramets, which are typical of clonal reproduction (Callaghan et al., 1990; Versieux, 2011). Individuals with identical ISSR markers (probably clones) in Population 1 (Peão) suggest that individuals isolated by short distances $(<1 \mathrm{~m})$ could be previously linked. This fact has also been reported for another species of the Bromeliaceae, Encholirium biflorum (Mez) Forzza, which possesses a clonal habit and occurs isolated or in small clumps spread out on sandy-rocky soil (Cavallari et al., 2006). However, these observations for E. biflorum and $V$. cacuminis may not be very common. The variability among populations of $V$. cacuminis ranged from 16 to $19 \%$, also suggesting the occurrence of 
outcrossing. Unfortunately, there are no data about the reproductive system of $V$. cacuminis. Autocompatibility is predominant within the genus (e.g., Siqueira-Filho, 2006; Matallana et al., 2010), although autoincompatibility has also been reported (Matallana et al., 2010). Regardless of the existence of an autoincompatibility mechanism in $V$. cacuminis, the flowers are adapted to pollination by hummingbirds (tubular flowers, with conspicuous color, no odor and large nectar production) and pollen flow could occur even if selfing is detected (Linhart et al., 1987; Parra et al., 1993). Wind dispersal, which occurs in V. cacuminis, in addition to cross-breeding, can help to decrease the genetic differentiation between the patches along the range as was observed along the Cruzeiro range. The high levels of diversity estimated within each population could be explained by clone longevity, as described for other clonal species (Esselman et al., 1999; Cavallari et al., 2006).

It is possible that Populations 1 (Peão) and 3 (Serra Negra) had been founded by a small number of seeds from Population 2 (Cruzeiro). The higher similarity estimated among individuals of Serra Negra, compared to that found among individuals from the other populations, suggests a lower number of events of seed dispersal to Serra Negra. Possibly, the gene flow between the populations of the 2 ranges can be maintained by hummingbirds or bats, which are the most common pollinators of the Bromeliaceae (Benzing, 2000). This dispersal of pollen could also prevent the differentiation of $V$. cacuminis populations along those 2 hills. Nevertheless, we cannot rule out the possibility that these 2 areas had been recently colonized, and therefore the elapsed time has not yet permitted significant differentiation between those populations and Population 2 (Cruzeiro). Another hypothesis could be that those populations (from Ibitipoca and Serra Negra) were connected in the past forming one major continuous population. In this case, the time of isolation might not have been enough to allow high levels of genetic differentiation.

Considering that the amount of genetic diversity has a straightforward relationship with the evolutionary potential of one species, understanding the population structure is essential to take effective measures of variability management and conservation. Our results showed that it was possible to detect higher diversity indices of $V$. cacuminis populations at Ibitipoca State Park (protected area) than Serra Negra (unprotected area). The genetic similarity of all the populations investigated revealed that these populations are probably not isolated. Regarding the populations from Ibitipoca State Park, the larger number of genotypes within populations, and also the higher genetic variability in Population 2 (Cruzeiro) indicate this area as an important source of genetic variability. Moreover, in addition to the higher variability, the large number of different individual genetic profiles also indicates that a great number of individuals should be collected to get a representative germplasm collection.

Although the present results help to explain how $V$. cacuminis populations keep their variability, it is important to check how far other processes such as self-fertilization and vegetative reproduction have affected the population structure.

In conclusion, despite restricted distribution, $V$. cacumins exhibited relatively high diversity within populations. The populations are located up to $30 \mathrm{~km}$ between each other and do not seem to be structured, perhaps as a consequence of sexual and asexual reproduction occurring simultaneously. Cross-breeding probably maintains the gene flow between the 3 existing populations and therefore the low level of differentiation between them. In each population, the longevity of clones probably contributes to maintaining different genotypes and increasing diversity within groups. The widest variability was detected within Ibitipoca State Park, whereas Serra Negra exhibited an outlying population, with less genetic variability. 


\section{ACKNOWLEDGMENTS}

Research supported by FAPEMIG and Rio de Janeiro Botanical Garden. R.C. Forzza, M.A. Machado, and L.F. Viccini are recipients of CNPq Research fellowships.

\section{REFERENCES}

Barbará T, Martinelli G, Palma-Silva C, Fay MF, et al. (2009). Genetic relationships and variation in reproductive strategies in four closely related bromeliads adapted to neotropical "inselbergs": Alcantarea glaziouana, A. regina, A. geniculata and A. imperialis (Bromeliaceae). Ann. Bot. 103: 65-77.

Benzing DH (2000). Bromeliaceae: Profile of an Adaptive Radiation. Cambridge University Press, Cambridge.

Bussell JD (1999). The distribution of random amplified polymorphic DNA (RAPD) diversity amongst populations of Isotoma petraea (Lobeliaceae). Mol. Ecol. 8: 775-789.

Callaghan TV, Svensson BM, Bowman H, Lindley DK, et al. (1990). Models of clonal plant growth based on population dynamics and architecture. Oikos 57: 257-269.

Cavallari MM, Forzza RC, Veasey EA, Zucchi MI, et al. (2006). Genetic variation in three endangered species of Encholirium Bromeliaceae from Cadeia do Espinhaço Brazil detected using RAPD markers. Biodivers. Conserv. 15: 4357-4373.

Cruz CD (1998). Programa GENES: Aplicativo Computacional em Estatística Aplicada à Genética (GENES - Software for Experimental Statistics in Genetics), Viçosa. Avaliable at [http://www.ufv.br/dbg/genes/genes.htm]. Accessed July 14, 2012.

Drummond GM, Machado ABM, Martins CS, Mendonça MP, et al. (2009). Listas Vermelhas das Espécies de Fauna e Flora Ameaçadas de Extinção em Minas Gerais. 2nd edn. Fundação Biodiversitas, Belo Horizonte.

Esselman EJ, Jianqiang L, Crawford DJ, Winduss JL, et al. (1999). Clonal diversity in the rare Calamagrostis porteri ssp. insperata (Poaceae): comparative results for allozymes and random amplified polymorphic DNA (RAPD) and intersimple sequence repeat (ISSR) markers. Mol. Ecol. 8: 443-451.

Evanno G, Regnaut S and Goudet J (2005). Detecting the number of clusters of individuals using the software STRUCTURE: a simulation study. Mol. Ecol. 14: 2611-2620.

Excoffier L, Smouse PE and Quattro JM (1992). Analysis of molecular variance inferred from metric distances among DNA haplotypes: application to human mitochondrial DNA restriction data. Genetics 131: 479-491.

Ferreira M and Grattapaglia D (1998). Introdução ao Uso de Marcadores Moleculares em Análise Genética. Embrapa Cenargen, Brasília.

Forzza RC, Costa A, Siqueira Filho JA, Martinelli G, et al. (2013). Bromeliaceae in Lista de Espécies da Flora do Brasil. Jardim Botânico do Rio de Janeiro. Available at [http://floradobrasil.jbrj.gov.br/jabot/floradobrasil/FB66]. Accessed July 14, 2012.

Gitzendanner MA and Soltis PS (2000). Patterns of genetic variation in rare and widespread plant congeners. Am. J. Bot. 87: 783-792.

Han Y-C, Teng C-Z, Zhong S, Zhou M-Q, et al. (2007). Genetic variation and clonal diversity in populations of Nelumbo nicifera (Nelumbonaceae) in central China detected by ISSR markers. Aquat. Bot. 86: 69-75.

Hmeljevski KV, Reis A, Montagna T and dos Reis MS (2011). Genetic diversity, genetic drift and mixed mating system in small subpopulations of Dyckia ibiramensis, a rare endemic bromeliad from Southern Brazil. Conserv. Genet. 12: 761-769.

Holsinger KE and Gottlieb LD (1991). Conservation of Rare and Endangered Plants: Principles and Prospects. In: Genetics and Conservation of Rare Plants (Falk DA and Holsinger KE, eds.). Oxford University Press, Oxford, 195-223.

Huang Y, Ji K, Jiang Z and Tang G (2008). Genetic structure of Buxus sinica var. parvifolia, a rare and endangered plant. Sci. Hortic. 116: 324-329.

Hubisz MJ, Falush D, Stephens M and Pritchard JK (2009). Inferring weak population structure with the assistance of sample group information. Mol. Ecol. Resour. 9: 1322-1332.

Jacques-Felix H (2000). The discovery of a bromeliad in Africa, Pitcairnia feliciana. Selbyana 21: 118-124.

Linhart YB, William HB, James HB and Peter F (1987). Forager behavior, pollen dispersal, and inbreeding in two species of hummingbird-pollinated plants. Evolution 41: 679-682.

Lousada JM, Borba EL, Ribeiro KT, Ribeiro LC, et al. (2011). Genetic structure and variability of the endemic and vulnerable Vellozia gigantea (Velloziaceae) associated with the landscape in the Espinhaco Range, in southeastern Brazil: implications for conservation. Genetica 139: 431-440. 
Luther HE (2010). An Alphabetical List of Bromeliad Binomials. Mary Selby Botanical Gardens and Sarasota Bromeliad Society, Sarasota.

Martinelli G, Vieira CM, Gonzalez M, Leitman P, et al. (2008). Bromeliaceae da mata atlântica brasileira: lista de espécies, distribuição e conservação. Rodriguésia 59: 209-258.

Matallana G, Godinho MAS, Guilherme FAG, Belisario M, et al. (2010). Breeding systems of Bromeliaceae species: evolution of selfing in the context of sympatric occurrence. Plant Syst. Evol. 289: 57-65.

Meloni M, Perini D, Filigheddu R and Binelli G (2006). Genetic variation in five Mediterranean populations of Juniperus phoenicea as revealed by inter-simple sequence repeat (ISSR) markers. Ann. Bot. 97: 299-304.

Menini LN, Matozinhos CN, Abre NL, Valente ASM, et al. (2009). Flora vascular não-arbórea de uma floresta de grota na Serra da Mantiqueira, Zona da Mata de Minas Gerais, Brasil. Bio. Neotrop. 9: 149-161.

MMA (2008). Lista Oficial das Espécies da Flora Brasileira Ameaçadas de Extinção. Instituição Normativa No. 6. DOU 23 de Setembro de 2008, Brasília.

Monteiro RF and Forzza RC (2008). A Família Bromeliaceae no Parque Estadual do Ibitipoca, Minas Gerais, Brasil. Bol. Bot. Univ. São Paulo 26: 7-33.

Neel MC and Cummings MP (2003). Effectiveness of conservation targets in capturing genetic diversity. Conserv. Genet. 17: 219-229.

Parra V, Vargas CF and Eguiarte LE (1993). Reproductive biology, pollen and seed dispersal, and neighborhood size in the hummingbird-pollinated Echeveria gibbiflora (Crassulaceae). Am. J. Bot. 80: 153-159.

Pritchard JK, Stephens M and Donnelly P (2000). Inference of population structure using multilocus genotype data. Genetics 155: 945-959.

Siqueira-Filho JA (2006). Floração e Polinização das Bromélias da Mata Atlântica Nordestina. In: Fragmentos de Mata Atlântica do Nordeste - Biodiversidade, Conservação e suas Bromélias (Siqueira-Filho JA and Leme MC, eds.). Andrea Jakobsson Estúdio, Rio de Janeiro, 158-189.

Slatkin M (1987). Gene flow and the geographic structure of natural populations. Science 236: 787-792.

Sneath PH and Sokal RR (1973). Numerical Taxonomy the Principles and Practice of Numerical Classification. W.H. Freeman and Company, San Francisco.

Souza HAV and Lovato MA (2010). Genetic diversity and structure of the critically endangered tree Dimorphandra wilsonii and of the widespread in the Brazilian Cerrado Dimorphandra mollis: Implications for conservation. Biochem. Syst. Ecol. 38: 49-56.

Versieux LM (2011). Brazilian plants urgently needing conservation: the case of Vriesea minarum (Bromeliaceae). Phytotaxa 28: 35-49.

Versieux LM and Wendt T (2007). Bromeliacea diversity and conservation in Minas Gerais State, Brazil. Conserv. Genet. 16: 2989-3009.

Viccini LF, Costa DSC, Machado MA and Campos AL (2004). Genetic diversity among nine species of Lippia (Verbenaceae) based on RAPD markers. Plant Syst. Evol. 246: 1-8.

Wolfe AD (2005). ISSR techniques for evolutionary biology. Methods Enzymol. 395: 134-144.

Yeh FC, Yang RC, Boyle TBJ, Ye ZH, et al. (1997). POPGENE, the User-Friendly Shareware for Population Genetic Analysis Molecular Biology and Biotechnology Center. University of Alberta, Edmonton. Available at [http://www. ualberta.ca/ fyeh/]. Accessed July 14, 2012. 